\title{
Creating effective advisory boards for schools of nursing
}

\author{
Marie-Noel Appel \\ Fairfield University, nappel@fairfield.edu \\ Suzanne H. Campbell \\ Fairfield University, suzanne.campbell@nursing.ubc.ca
}

N. Lynch

\section{Jeanne Novotny}

Fairfield University, jnovotny@fairfield.edu

Follow this and additional works at: https://digitalcommons.fairfield.edu/nursing-facultypubs

NOTICE: this is the author's version of a work that was accepted for publication in Journal of Professional Nursing. Changes resulting from the publishing process, such as peer review, editing, corrections, structural formatting, and other quality control mechanisms may not be reflected in this document. Changes may have been made to this work since it was submitted for publication. A definitive version was subsequently published in Journal of Professional Nursing, [23, 6 (2007)] DOI: 10.1016/j.profnurs.2007.06.020

\section{Repository Citation}

Appel, Marie-Noel; Campbell, Suzanne H.; Lynch, N.; and Novotny, Jeanne, "Creating effective advisory boards for schools of nursing" (2007). Nursing and Health Studies Faculty Publications. 4.

https://digitalcommons.fairfield.edu/nursing-facultypubs/4

\section{Published Citation}

Appel, N., Campbell, S.H., Lynch, N., Novotny, J. (2007).Creating effective advisory boards for schools of nursing. Journal of Professional Nursing, 23(6), 343-350.

This item has been accepted for inclusion in DigitalCommons@Fairfield by an authorized administrator of DigitalCommons@Fairfield. It is brought to you by DigitalCommons@Fairfield with permission from the rightsholder(s) and is protected by copyright and/or related rights. You are free to use this item in any way that is permitted by the copyright and related rights legislation that applies to your use. For other uses, you need to obtain permission from the rights-holder(s) directly, unless additional rights are indicated by a Creative Commons license in the record and/or on the work itself. For more information, please contact digitalcommons@fairfield.edu. 


\section{Creating Effective Advisory Boards for Schools of Nursing}

Noel Appel, BA

Fairfield University

1073 North Benson Road

Fairfield, CT 06824

203-254-4000, ext. 2025

nappel@mail.fairfield.edu

Suzanne Hetzel Campbell, Ph.D, APRN-C, IBCLC

Fairfield University

1073 North Benson Road

Fairfield, CT 06824

203-254-4000, ext. 2578

scampbell@mail.fairfield.edu

Nancy Lynch, BA

15 Quail Road

Greenwich, CT 06831

NLynchCT@aol.com

Jeanne M. Novotny, Ph.D., RN, FAAN

Fairfield University

1073 North Benson Road

Fairfield, CT 06824

203-254-4000, ext. 2700

jnovotny@mail.fairfield.edu

Abstract 
Increasingly, a significant priority for the dean and the faculty in schools of nursing centers on fundraising. Raising financial resources is highly competitive and requires sophisticated approaches to build relationships with individual donors, government agencies, private foundations, and corporations. Schervish, O'Herlihy \& Havens, 2002 state that, "Individuals give by far the largest share of charitable contributions to nonprofit organizations.” (p. 2). Therefore, fundraising efforts need to be designed to cultivate alumni, parents, and friends as key leaders educated in the work of the school, its vision for the future, and the nursing profession. Advisory boards, with an emphasis on development, can effectively nurture such leaders who are fully versed in the nursing school's strategic vision and willing to provide financial support as well as access to a broad community of interest. An integrated approach that capitalizes on the expertise and knowledge of the dean, the faculty, the development officers, and a carefully selected board chair forms the foundation of a successful model for development focused advisory boards. Advisory board implementation is discussed from the perspective of a clearly articulated board charge, selection and recruitment, a board retreat, assessing interest and inclination through an annual board planning process, engagement in priority project planning with the faculty, and careful cultivation toward funding. 


\section{Development Advisory Boards for Schools of Nursing}

According to Lee (1994), “The simple definition of an advisory committee is a group of volunteers that meets regularly on a long-term basis to provide advice and/or support to an institution or one of its subunits" (p. 1). Lee (1994) goes on to observe that leadership boards can "increase a school's opportunity to work with external constituents by providing fresh insights, powerful connections, access to valuable resources and excellent public relations" (p. 1). Successful advisory boards often have the following characteristics:

- Committed deans, faculty, and advancement staff.

- Knowledgeable board members who are advocates of the school's work.

- Defined procedures that outline responsibilities and opportunities for access to program information (Lee, 1994).

The establishment of school-based advisory boards and fundraising is rapidly becoming an expectation of deans and faculty members in non-research intensive universities. As schools are confronted with shrinking resources, this activity is of paramount importance because it results in decision making about the allocation of precious resources. It is also an intellectual activity which is critical to the development of excellent programs, important projects, and opportunities for faculty development that reflect the mission, culture, and values of the school and the institution. (Larsen, 1993). Deans and faculty members are now expected to initiate and manage a wide range of activities in concert with the development and advancement officers of the larger university. No one prepares the dean or faculty member for interface with a board or with the responsibilities of fundraising. These skills are expected but not explicitly taught.

There are several common myths or misperceptions regarding fundraising activities:

- No special skills are required of the dean, faculty members, or staff involved.

- Primary responsibility belongs to the development officer or liaison. 
- Funds will be generated automatically if academic and clinical programs are strong.

- Fundraising is separate and apart from the mission of the organization. (Fitzpatrick \& Deller, 2000)

Giving USA (2005) provides further evidence that thoughtful work associated with individual cultivation is worthy of serious attention in their report which states that, "Individual giving, the single largest source, rose by an estimated 4.1 percent in 2004 to reach $\$ 187.92 ”$ (p. 1)

The literature revealed numerous articles and books on advisory board implementation for nonprofit organizations, many of which were reviewed in the preparation of this article. However, very few published methods describing the effectiveness of this type of board for a nursing school were identified. This article seeks to fill this gap.

Evidence of the national interest and necessity for this type of work in higher education was recently seen at the CASE (Council for the Advancement and Support of Education) Development for Deans: Winter Session 2006 in San Diego, Cal. Of the more than 250 attendees, approximately 50 percent of the participants represented the academic division of schools across the country, including deans, faculty, academic vice presidents, and provosts. These individuals, many of whom attended together with their development officers, came together to acquire knowledge about best practices in the area of schoolbased fundraising. During an intensive three-day program, participants learned about the major gift cycle, how to manage advisory boards, and effective ways to work with alumni, parents, and friends of the institution with an emphasis on development. The necessary skills, responsibilities, and strategies for raising funds effectively through leadership boards were covered during this program.

A substantial amount of the work underway in the area of school-based advisory boards is happening at large institutions across the country. Many of these schools are organized in a decentralized model with specific development officers assigned to individual schools. At Fairfield University in Connecticut, a Masters I Jesuit university founded by the Society of Jesus in 1942, significant work has been done related to school-based development advisory boards. The School of Nursing was opened in 1971 and is one of six schools at Fairfield, each with a dean who reports directly to the academic vice 
president. The experience at Fairfield has been unique, in part, because of its size, serving a total of 5,000 undergraduate and graduate students, as well as the fact that Fairfield operates with a traditional centralized Advancement model. The School of Nursing launched the first development board at Fairfield in 2005. The strategic vision for programs in the school revolve around four main themes: care of older adults, palliative care, community partnerships, and international collaboration. These themes provide the foundation for all fundraising initiatives.

Setting a Course for the School of Nursing Advisory Board

Typical questions that deans, faculty, and development staff ask related to the design and implementation of school-based development boards include the following:

- What is an effective size for a leadership board of this kind?

- Should board members be required to contribute to the school of nursing?

- What is the frequency of meetings and how many are required?

- What is the content of the meetings and how are they structured?

- What criteria should be considered in the selection of a board chair?

- How should university staff and board members be educated in effective board implementation strategies?

- What do you expect of the board members?

- What is the role of the dean and faculty?

With this article we seek to present the reader with the distinctive perspectives of four key players in the design and implementation of the School of Nursing Advisory Board at Fairfield University. All of the questions listed here are addressed by the dean, the faculty board liaison, the advancement liaison, and the board chair providing their unique perspective on the formation and continued implementation of a rigorous fundraising board in full operation in the School of Nursing. It should be noted that a comprehensive workshop has been developed by this team which was recently presented at the March 
2006 American Association of Colleges of Nursing Advancement Professionals meeting in Washington, D.C.

In 2004, Fairfield University welcomed its eighth president, Rev. Jeffrey von Arx, S.J., who challenged university leadership to create rigorous school-based boards that would serve as hallmarks of a partnership between the Advancement and Academic Divisions. This approach was echoed by a former trustee and seasoned philanthropist who, in discussions with representatives of the Advancement Division and the School of Nursing, suggested that a development-focused advisory board with a complementing lecture series would provide the necessary leadership and visibility to achieve significant growth.

The School of Nursing had a board in place that primarily represented the clinical sites, employers, community members, and leaders in the external community of interest. This board, called the partnership council, meets twice a year, and does not have fundraising as part of its charge. The establishment of this new leadership board, the School of Nursing Advisory Board, does have fundraising as its charge. It should be noted that this board does not have fiduciary responsibilities which are the concern of the University's Board of Trustees. The following objectives were considered as this board was developed:

- Restructure staff in Advancement to support this new development framework;

- Define volunteer engagement in new ways through establishing a clearly defined board charge and thoughtful criteria for board member selection;

- Expand roles and responsibilities for the dean, the faculty, and administrative support personnel articulated in concrete job descriptions;

- Design a two-day intensive board retreat model to launch the work of the volunteers, the board chairs, and the University effectively;

- Produce clearly defined fundraising priorities that complement strategic long-range programmatic goals in the School of Nursing; 
- Integrate Development Office services and support between various departments within the

Advancement Division and between the larger Academic and Advancement Divisions; and

- Develop a protocol for volunteer activity tracking and related information database.

During the winter of 2005 to the present, a development-focused leadership board has been designed and implemented for the School of Nursing, and the objectives listed above have guided the process. A total of 11 volunteers have been thoughtfully educated and nurtured to serve as champions of the strategic direction of the school. They represent alumni, parents, and friends of the institution as well as private foundations and corporations. The goal is to increase this number to 20 board members committed to serving a three-year term renewable based on interest and record of participation. The initial core group of board members will help to reinforce the next phase of recruitment, making the work of the board highly appealing to other candidates (Maude and Heap, 1997). These volunteers and the board chair are working side-by-side with the dean and faculty to bolster financial resources and extend the community of interest for the School of Nursing.

\section{Development and Implementation of the Plan}

With the generous support and guidance of the seasoned philanthropist mentioned above, the School of Nursing faculty worked with a newly-appointed School of Nursing advancement division liaison to research school-based leadership boards and public lecture series at nursing schools across the United States. This work resulted in two proposals for funding that were ultimately supported with a total of $\$ 90,000$ in grants and gifts: $\$ 14,000$ for the launch of the new board and $\$ 76,000$ for a three-year lecture series. The development process for the advisory board proposal resulted in the design of an implementation plan for a leadership board of this kind based on a careful review of best practices at other institutions of varying size. The vision for this work was defined by six nursing faculty and the dean, working in partnership with Advancement.

The proposal design process for the advisory board resulted in the identification of the implementation objectives outlined above. Each objective had a related series of action steps which are described below. 
- Advancement Staffing Restructuring - A School-Based Advancement Liaison position was articulated by the Advancement Division to support the establishment and maintenance of school-based boards. Two staff members in Advancement were given responsibility for two schools each, including the School of Nursing, the College of Arts and Sciences, the School of Business, and the School of Engineering. It should be noted that two schools at Fairfield chose to launch development boards while two others elected to implement a more traditional format for their boards with a primary focus on strategic planning and school-based advocacy.

- Defining Volunteer Engagement - Three members of the Advancement staff, together with two board members from the School of Nursing, attended a full-day workshop at the Foundation Center conducted by BoardSource entitled, Nonprofit Boards and Fundraising, with the express purpose of learning about the design and implementation of boards with a development focus. Shortly thereafter a multi-page Board Charge was drafted and vetted with the School of Nursing dean, her counterpart in the College of Arts and Sciences, and the Advancement Division. The Board Charge is a recruitment and education tool which highlights key roles and responsibilities, the policy on board-member giving, options for individual board member participation, fundraising activities, and job descriptions. The essential nature of a clearly defined board charge is echoed by Maude and Heap (1997) in which they state, "The process begins with a written description of the program you want to address, the parameters within which the council will be focused, the results you are seeking, and a plan to guide the development. This clearly defines the strategies, people, and resources which will assure success of the effort" (p. 1). At Fairfield it was determined that the two schools interested in testing this development board model would adopt the same board charge for institutional consistency and efficiency. The criteria for board member selection was developed for the School of Nursing based on current priorities, history of giving, knowledge of philanthropy, and commitment to the profession of nursing. Maude and Heap (1997) suggest that the board member selection process should include answering the following questions:

- "With what other organizations is this candidate currently involved? 
- Is the focus of this advisory council an opportunity to advance his/her interests?

- Why would this candidate be willing to serve?

- What financial resources could he/she bring to the project?

- What is the best approach to recruit this individual?

- Who should be involved?” (p. 2).

The board selection and recruitment process can serve as a blueprint for cultivation of each candidate. Assessing what stage the candidate may be at in terms of current involvement with the organization and mapping out an approach that recognizes the depth of the current relationship helps advance their longer term commitment to the institution (Maude and Heap, 1997).

- Job Descriptions - A substantial component of the day-to-day staffing structure to support the work of the development-focused volunteer board was established in the office of the dean. A natural outgrowth of the process to define the job descriptions in the Board Charge was the clear articulation of new responsibilities for the dean, the faculty, and the administrative support personnel.

- Board Retreat Model - In January 2005, the School of Nursing contracted with consulting services at the University of Maryland on Board Development. The primary responsibility of the identified consultant was to assist in the process of designing and implementing a two-day board retreat. With substantial input from the Fairfield team, this retreat was conducted in June 2005 for the board members. The dean, the board chair, and the advancement liaison were actively engaged in all of the planning for the retreat as well as part of the implementation leadership team. The primary objective of the retreat was to familiarize the board with the School, one another, and their responsibilities and opportunities for engagement. During Day One of the retreat, faculty and students engaged the board members in a comprehensive introduction to the work of the School of Nursing. During Day Two of the retreat, University staff, including the President, Vice Presidents for Finance and the Academic Division, and Advancement provided the institutional context within which the board's work would be accomplished. The second half of the second day included various activities and presentations designed to focus the 
Board specifically on their work providing strategic direction and development support. Additional information about the Board Planning Tool is provided in this article in the section entitled, Board Member Engagement. It is expected that the retreat model will be utilized again in a modified format as an orientation tool for newly recruited members. The retreat model designed and tested by the School of Nursing was later adapted and conducted by the College of Arts and Sciences for its new twenty member board.

- Fundraising Priorities - A faculty team was responsible for defining the priority project design, proposal, and budget. The selected project is linked to the strategic vision for the continued growth of the school, as well as the University's continued growth. A \$1 million Learning Resource Center proposal was completed by Nursing with support from Advancement during the course of this academic year, and the fundraising for this initiative is now well underway. This initiative outlines the framework for a comprehensive enhancement to laboratory and classroom space utilizing simulation tools and teaching technology along with a four-year faculty and curriculum development plan. It will impact every aspect of undergraduate and graduate pedagogy. Additional details about this project and the process adopted to effectively design it are provided in the section entitled, Implementation Team Perspectives: Faculty Board Liaison. Establishment of the funding priority and the related proposal and budget serves to clearly define the board's work. Maude and Heap (1997) add, "The focus area may be the development of a new program, expansion or evaluation of a current program, funding of a program that is not self-supporting or establishment of an endowment" (p. 3).

- Integration of Development Office Services - Regular and thoughtful discussions ensured that the work of the Offices of Annual Fund, Development Services, Major Gifts, Foundation Relations, and Corporate Relations were all part of an integrated approach to supporting the school-based board. Major gifts staff members assigned to specific Board members worked closely with the dean on a regular basis, while the fundraising efforts of Corporate and Foundation Relations continued to map out grant activity in relation to the fundraising priority. Reports were produced monthly highlighting the work underway for 
Development staff. Periodic reports were prepared for the Board of Trustees, as were reports to the dean of the School of Nursing and the Academic Vice President.

- Volunteer Activity Tracking - The dean, faculty members, and administrative staff were educated about the necessity of tracking visits and contact with volunteers for documentation in the Advancement database. Faculty and the dean are aware of the necessity of preparing detailed summaries in the form of call reports that reflect meaningful interaction with board members through phone calls, visits, and other special events. This information is shared with the Advancement Liaison and then is entered into the permanent Banner record for the constituent. Additionally, the Advancement Liaison worked with Development Services to create an Access database for the School that downloads information directly from the Banner system on each of the Board volunteers for the production of mailings, name tags, and other printed materials. Changes in address and other contact information for board members is shared with the Advancement Liaison by the School of Nursing administrative staff so that the Banner system can remain up-to-date. According to Maude and Heap (1997), "Documentation, from beginning to end, yields strategic management and control. It's useful for defining direction, critical to maintaining momentum, essential to achieving success, and vital to building trust" (p. 5). Comprehensive tracking of activity with board members ensures that major gifts staff and others involved in the on-going cultivation plans for these individuals have access to the most curent information at all times.

\section{Board Member Engagement}

The primary objective of this work with the advisory board is to cultivate a leadership team that can serve as effective advocates and friends of the School of Nursing. The framework that serves as a backdrop to this work is similar to the cycle for major gift fundraising that most development officers are familiar with, which includes identification, cultivation, solicitation, and stewardship. Maude and Heap (1997) make the same correlation between effective board member cultivation and the major gifts cycle, highlighting the "Seven I's" concept of "identify, inform, interest, involve, internalize, invest, and immortalize" (p. 8). First and foremost, this process at Fairfield has capitalized on the expertise and knowledge of the board chair who fully embraces all aspects of the board members' roles and 
responsibilities and articulates them consistently so that there is significant clarity of purpose at all times. When a question arises related to individual board member giving, it is essential that the chair naturally addresses this point as a fundamental responsibility of the board members first and then an expanded community of interest that they are charged with helping to identify. The guiding principles that have helped to shape all aspects of the board meeting design process and work with the board members over the last twelve months include the following:

- Regular and meaningful opportunities for education about the nursing profession and the Fairfield School of Nursing's strategic vision for growth;

- Diverse and thoughtful volunteer engagement tailored to the interests and expertise of each board member working in consultation with the dean and the faculty;

- Individual cultivation plans designed by major gifts staff that complement the activity and work of the board as a whole utilizing the dean, the president, and the board chair; and

- Concrete and purposeful meeting designs that are seamlessly connected and address anticipated outcomes.

Mapping the board's work started at the kick-off retreat and included the design and implementation of a Board Planning Tool in which board members self-identified their areas of interest by rating selected activities - high, medium, and low. This information was used to chart a course for individual board member action plans that were fine-tuned to the specific interests and inclinations of the board members. See Table 1 for the Board Member Planning Tool.

The advisory board had its kick-off retreat in June 2005 over a two-day period with the primary purpose of launching its work. The three required board meetings conducted between September 2005 and June 2006 have had carefully planned objectives designed to build seamlessly on the retreat and on each consecutive meeting. Orchestrating the work of the board is a comprehensive process that requires substantial collaboration among the dean, the chair, and the advancement liaison. Maude and Heap (1997) confirm this stating, "Planning meetings with the chair and champion, strategically drafting minutes, 
thoughtfully planning tasks for council members to execute; this entire process must be conducted in a professional, inclusive, sincere manner" (p. 5). The first meeting (October) and a small portion of the second meeting (January) focused on the Learning Resource Center fundraising priority with the express purpose of deepening the board's knowledge of the project. Additionally, these meetings were designed to provide the board with opportunities to critique and assess the emerging project design and lend their expertise to the final product inclusive of the implementation plan and the budget. The second meeting (January) had as its primary focus the work of the Development Office and how that translated into a resource to the board members in their fundraising function as donors and as ambassadors to a broader community of new friends. The final board meeting for the 2005-06 academic year (June) will address fundraising progress toward the $\$ 1$ million goal for the Learning Resource Center and new directions in the School of Nursing.

Individual board member volunteer engagement has been a parallel activity that has been guided, in part, by areas of interest identified in the Board Planning Tool and by carefully listening to individual board members as the work has unfolded. Expanded opportunities for engagement with the faculty has been a central objective of this aspect of the work, since almost all of this activity involves the faculty. Some examples of meetings/activities that have taken place throughout the academic year that have actively engaged individual board members drawing on their unique expertise include:

- Attendance at meetings with Laerdal, simulation equipment vendor for the Learning Resource Center project;

- Participation on the leadership team for the planning and design of a grant initiative in palliative care;

- Involvement as panel presenters at a School of Nursing professional development day providing current perspectives on partnerships in nursing for the future;

- Authoring articles that reflect on the unique perspective of board members in relation to special programs in the School of Nursing for publication in the School of Nursing newsletter; and 
- Participation of the chair in this article and on the presentation team as part of the dissemination of this work to other schools across the country.

According to Maude and Heap (1997), "Guiding the council is a cyclical process: observing people and their discussion, formulating the next steps, etc. This cycle will continue through the life of the council and the process will become more complex as the council moves forward" (p. 5).

Implementation Team Perspectives

\section{Advancement Liaison}

The essential components that have guided Fairfield's work with the school-based development boards include: 1) significant institutional commitment from the president, the dean, and the Advancement Division; 2) the selection of a dynamic chair with a deep sense of commitment to the school and expansive knowledge of fundraising; 3) a nursing school with a visionary leader who has ensured that the faculty and supporting staff across the institution are energized and motivated to work in a highly collaborative manner to realize the strategic vision for the school; 4) talented faculty members who have fully embraced the process of researching and defining highly competitive projects for funding that advance the school's growth; and 5) an integrated development team that works together selecting the most effective and committed board members who will be cultivated through a partnership approach that includes the dean, the board chair, the faculty liaison, and the assigned major gifts officer.

Given Fairfield's centralized development structure, it has been essential that the dialogue and communication about the work of the board be completely transparent to all members of the development team. The advancement liaison position is a new approach at Fairfield, and the most important challenge has been to establish meaningful responsibilities for the liaison in support of the dean and the advisory board while simultaneously recognizing and supporting the essential role of the major gifts office in this new model. Regular opportunities for professional development that include the broadest possible representation from the full leadership team have been very effective. Some of the resources that Fairfield has successfully taken advantage include BoardSource, the Council for the Advancement and Support of Education, and the Foundation Center. 
In preparation for the January 2006 School of Nursing Advisory Board meeting, members of the Development team came together to design a comprehensive presentation. It was developed to educate the board members about the history of development at Fairfield, the major gifts fundraising process, foundation and corporate grant fundraising, and the board members' specific roles and responsibilities as donors and ambassadors to the broader community. This exercise provided the Development team with a unique opportunity to reflect on its work and how best to communicate this activity to an audience of individuals who have agreed to serve as ambassadors of the development function for Fairfield University. It is expected that this workshop will be refined over time, and that a more detailed version of specific portions of it will form the foundation of other sessions for board member education and training. Where appropriate, external consultants may be invited to join the development staff in their efforts to further refine and expand board member, faculty, administration, and staff knowledge of the development function and how it can best serve the long-term fundraising goals of the School of Nursing. BoardSource (2005) confirms the need for continuous education of board members, stating, "Exceptional boards invest time and resources in board development. Over time, board members deepen their commitment to the organization, making them increasingly valuable to its success.” (p. 22).

\section{Faculty Board Liaison}

Faculty members have very little understanding of the goals and work of the Advancement Office. In reality, their experience may be limited to annual contact by alma maters for donations. The experience with the Advancement Office at Fairfield University and the School of Nursing Advisory Board provided much insight into the internal workings of the University itself, and the importance of partnerships between Advancement, the dean, the faculty, and the advisory board. Faculty had the opportunity to share with the advisory board passions about nursing, health care, and visions for the future. Much of the faculty role and responsibilities occur behind the scenes; this allowed the opportunity 
to "shine," to describe some of the specifics of nursing faculty work clinically, scholastically, and in service to the University and surrounding community. With the help of students, the faculty painted a picture for the advisory board of what really happens within and outside the walls of the School of Nursing. Current accomplishments and future visions were a major focus of the interchange. This process also required a focus of energies to describe a concrete future goal and vision with the guidance and support of the dean and the Advancement Office. In developing a project goal, statement, and budget, there was clarity of purpose. A challenge was maintaining a broad overview of the process, including building updates, technology and equipment refinement, as well as faculty development and support.

Key to the growth of this faculty board liaison role has been an involvement on all levels. It began with introducing the board to the School of Nursing, including its past accomplishments, present strengths, and future visions. This meant introducing the board to faculty, students, and alumni with a passion for the school and the ability to articulate their experiences. These same groups represented the School at the lecture series and dinner in October of 2005, providing a more formal atmosphere yet still relaxed with opportunities for one-on-one conversations. Allowing the board a more personal view of the School and the lives of those involved in its day-to-day activities enhanced the sense of intimacy and commitment. After the well-attended lecture series, the board meeting the following day provided an opportunity to debrief and recognize the success of the event. There was a sense of awe in the air, as the Board, dean, development liaison, and faculty liaison recognized the intense community interest and commitment to the School of Nursing. Clearly the topic was near and dear to the community's heart, as the auditorium was literally filled to "standing room only" capacity. What the School of Nursing represented and how much it was accomplishing in the community seemed to be most inspiring to all those gathered. Finally, at this board meeting, presentation of the vision of simulation-focused pedagogy, and a more defined vision for the renovation of the Learning Resource Center, enhanced the Board's understanding of the School's needs.

Throughout the rest of the year, meetings were held with University groups, including Operations Management, Lab Director, Computing and Network Services, and Institutional Technology, to plan the 
specifics for the building renovations, technology upgrades, and equipment needs. In addition, the Center for Academic Excellence was key in providing guidance and budgeting for faculty development needs and resources. Finally, faculty development began in the areas of simulation scenario writing, with input from Health Communications, Visual and Performing Arts, and the Media Center. Development has begun integrating some of the new technology and software into the nursing curriculum with wonderful results, including increased faculty and student interaction and satisfaction.

The faculty role as advisory board liaison and project director for the Learning Resource Center has melded beautifully to add to the success of this board. The dean's commitment to release time for faculty for these roles, and for faculty conference attendance, site visits, and consultation has also been an important aspect of this success. Finally, the incredible support of colleagues, who encouraged, supported, and assisted in the development of this new role, added to the personal growth of all those involved.

Over the past year, the role of faculty board liaison has led to the privileged opportunity of getting to know members of the board on a more personal level. Their individual passion and gifts when it comes to supporting the School of Nursing was striking. "Advocacy" does not seem like a strong enough word to describe the friendship, empathy, and a deep sense of giving back for those involved. Their role modeling and unselfish desire to share the vision of the School of Nursing and Fairfield University was awe-inspiring to the faculty board liaison. A deep sense of humility and recognition of the strong positive influence this experience has had on one's professional and personal life have been the greatest benefits of this role.

\section{Board Chair}

It is extremely important that the board chair have a deep understanding and appreciation of Fairfield's Jesuit tradition and mission of the School. The chair is the executive officer of the Advisory Board and presides over all meetings, assists in the development of agendas, and works with the Development staff to establish fundraising strategies for priority projects.

Having been involved with fundraising for many years and most importantly in the field of healthcare is a great advantage to this role. It is essential that the person in this position be the 
"cheerleader" who encourages other members of the board to solicit gifts and participate in fundraising activities. S/he should work to the strength of each board member strength and use those strengths accordingly. The key is that each member feel passionate about the work and have the desire and ability to participate in the "ask." If, however, they are not as comfortable doing this, it is important to redirect their involvement other areas that will bring about the same results. The board chair should accompany the Dean and Advancement staff in asking for a contribution, as it is very important that these three leaders compliment one another and come together as a strong team.

It is essential that the board chair set by example. Each member is expected to make the School of Nursing a philanthropic priority and support fundraising strategies through personal influence with others. An annual contribution according to personal needs is highly encouraged.

It is also critical that board members participate in three board meetings each year along with other events and activities. As the major spokesperson for the board, the board chair is responsible for overseeing these meetings and fostering planning and advising, fundraising, cultivation, and stewardship.

The board chair fills a very important role as a leader but must listen closely to the needs and requirements of the faculty and administration of the School of Nursing, keeping ever vigilant of their initiative. First and foremost, their role is to make sure they understand the vision and goals of a new state of the art Learning Resource Center and what it will do for the nursing students of the University now and for years to come.

\section{Dean}

From the perspective of the dean, the great camaraderie that was shared by all involved in this initiative and the fact that fundraising was related to the mission and strategic vision of the School was a key factor in achieving success. The four themes of the School were emphasized in all activities, reflected the expertise of the faculty, and furthered the mission of the University as well as the nursing profession. The message was always clear, unambiguous, and targeted toward these important goals. The selection of the board chair and the relationship between the dean and the chair was a critical element. Our chair was experienced and skillfully guided the process in helping to identify goals that met the needs of both the 
donor and the School. The dean was completely involved in building and sustaining relationships, keeping the lines of communication open, and always aware of Advancement cultivation activities.

The process of fundraising provided the School of Nursing direction for the allocation of resources, helped guide faculty research and scholarship to keep it aligned with the mission, and focused on outcomes that are important for the profession. The development of the fundraising advisory board gave visibility to the work of nursing and formal articulation of the way that the Advancement and Academic Divisions need to be intertwined. The role of the dean was completely enriched by the experience of the partnership between the advancement liaison, board char, and expert faculty.

\section{Budget Considerations}

The costs associated with the external retreat consultant and funding to send various Board members and staff to conferences was covered by a one-time grant of $\$ 14,000$. Costs include staff time for the dean, administrative support, and Faculty Board Liaison, as well as three Board meetings, special events, and conference and fundraising related travel. The total cost for the School of Nursing for FY '06 was $\$ 32,566$ for 11 Board members. The Advancement Liaison is compensated with an annual stipend, and additional budget allocations amount to approximately $\$ 10,000$.

\section{Evaluation}

The first measure of success relates to the framework of staffing and process that supported the launch and initial implementation of a school-based Advisory Board focused on development. All of the objectives associated with this component of the work have been accomplished. The next measure of the effectiveness of the board will be evaluated based on the fundraising activity that is successfully implemented through individual board-member giving, grants through foundation and corporate sources, and the expanded spheres of influence and access provided by board members. The effectiveness of the board, in part, is based on the results of the fundraising plan that was launched at the January board meeting. Success will also be measured based on the number of new funding prospects that emerge through the board and how successfully board members serve as champions for the priority projects. As a Jesuit University, with its focus on a responsibility to serving others, another measure of success will be 
based on successful sharing of our model with colleagues at other schools through publications and presentations. Table 2 provides a chart that outlines the assessment measures and the achievements realized to date.

\section{Conclusion}

The success of this new approach to school-based development will ultimately be measured by the quality, clarity, and depth of partnerships within the University and, more broadly, with the volunteers invited to participate in this endeavor. In the final analysis, the greatest measure of success will be how well the volunteers, faculty, deans, and Advancement staff understand and implement their respective roles in relation to the board's work. This process requires the establishment of clear goals, consistent internal and external communications, and a regular, fluid process for ongoing decision-making and dialogue between Divisions as opportunities and challenges arise. While the results of this work are still unfolding, those involved in the process recognize that substantial progress has been made.

There are many constituent groups that are impacted by this type of work, and one in particular is the faculty. Central to the faculty involvement is the faculty board liaison and the critical role that this individual facilitates related to the design and development of the priority fundraising project and a meaningful relationship with the extended faculty. The project development work has resulted in faculty development on simulation pedagogy, technology, and opportunities to tour other simulation labs in different locations. The vision has expanded to include both curricular, technological, and clinically focused additions including the School's past focus on geriatrics and the older adult, as well as spirituality and palliative care. In addition, implementation of an ePortfolio with students to begin to measure outcomes of the program from a student's perspective and to assist them to begin to identify professional goals, achievements, and development over their course of study will provide concrete evidence of the success of School of Nursing activities. Many of these achievements are connected to the changes made possible with the assistance of the advisory board as champions of the School's strategic long-range vision for growth. 
Advisory Boards for Schools of Nursing 21 


\section{Table 1}

\section{Board Planning Tool Template}

\section{Fundraising Goal}

As part of the $35^{\text {th }}$ Anniversary of the School of Nursing at Fairfield University, a fundraising effort is underway to raise $\$ 1$ million to enhance the educational resources available to the faculty and students. Specifically, funding will support the upgrade of the School's instructional laboratory and will provide technological enhancements for teaching classrooms in the School of Nursing. The overall initiative includes a four-year plan for faculty education and associated curriculum development to ensure that all of the new resources available in the lab and classrooms are fully integrated into the pedagogy delivered to undergraduate and graduate students at Fairfield.

\section{Board Participation Activities}

Lab/Classroom Project Case Statement - Provide feedback on project fundraising proposal, donor presentations, and related material.

University Strategic Plan Review - Attend special evening program to assist in vetting the First draft of the University's Strategic Plan (October 20, 2005).

Door Openers - Identify new friends (corporate, private foundation, and individuals) of the School of

Nursing from your spheres of influence.

Potential New Friends - Review potential donors researched by Fairfield's Office of Advancement Research.

$3^{\text {th }}$ Anniversary School of Nursing Dinner and Lecture - Participate in this program with Dr. Oliver Sacks, Wednesday, October 26, 2005.

\section{$3^{\text {th }}$ Anniversary School of Nursing Professional Development}

Saturday - Join the planning team for the design and implementation of this full day program Saturday, June 17, 2006.

$3^{\text {th }}$ Anniversary Dinners - Host a dinner to introduce

the dean and a faculty member to a select group of five to six new friends of the School of Nursing.

On-Campus Events - Help to organize special events

as identified by the School of Nursing.

\section{Expression of Interest \\ (high, medium, low)}

\section{Next Steps}


Table 2

Evaluation Summary

\begin{tabular}{|c|c|c|}
\hline Objective & Achievement & Volunteer/Staff Engagement \\
\hline $\begin{array}{l}\text { School-based Advancement } \\
\text { Liaison Job Description }\end{array}$ & Designed and completed & $\begin{array}{l}\text { Advancement Liaison, } \\
\text { Advancement Division, and Dean }\end{array}$ \\
\hline $\begin{array}{l}\text { Board Charge inclusive of } \\
\text { related job descriptions and } \\
\text { Board member selection } \\
\text { criteria }\end{array}$ & $\begin{array}{l}\text { Over } 25 \text { potential Board members } \\
\text { were identified, with } 11 \text { selected } \\
\text { and recruited. }\end{array}$ & $\begin{array}{l}11 \text { volunteers, -- Academic and } \\
\text { Advancement Division staff }\end{array}$ \\
\hline $\begin{array}{l}\text { Two-Day Advisory Board } \\
\text { Retreat }\end{array}$ & $\begin{array}{l}\text { Designed and implemented - June } \\
2005\end{array}$ & $\begin{array}{l}11 \text { volunteers, } 8 \text { Academic and } \\
\text { Advancement Division staff, } 8 \\
\text { students, } 10 \text { faculty }\end{array}$ \\
\hline Board meetings & Nursing (Oct./Jan./June) & $99 \%$ attendance of Board members \\
\hline $\begin{array}{l}\text { Priority fundraising project } \\
\text { proposals }\end{array}$ & $\begin{array}{l}\$ 1 \text { million Nursing project } \\
\text { proposal, budget, and marketing } \\
\text { materials. }\end{array}$ & 13 nursing faculty \\
\hline $\begin{array}{l}\text { Regular communication of } \\
\text { Board activity internally and } \\
\text { with the Board Chair }\end{array}$ & $\begin{array}{l}\text { Periodic reports within } \\
\text { Advancement; } \\
\text { ongoing dialogue between various } \\
\text { University staff and Board Chair }\end{array}$ & $\begin{array}{l}\text { Advancement Liaison, } \\
\text { Advancement staff, Dean, } \\
\text { Academic Vice President, Board } \\
\text { of Trustees. }\end{array}$ \\
\hline $\begin{array}{l}\text { School-Based Development } \\
\text { Board Educational } \\
\text { Conferences }\end{array}$ & $\begin{array}{l}\text { 1. Foundation Center (March } \\
\text { 2004) } \\
\text { 2. CASE Development for Deans } \\
\text { (February 2006) }\end{array}$ & $\begin{array}{l}\text { 1. } 3 \text { Advancement staff, } 2 \text { board } \\
\text { members. } \\
\text { 2. } 2 \text { Advancement staff } \\
\text { 3. } 1 \text { Advancement staff, dean, }\end{array}$ \\
\hline
\end{tabular}




\begin{tabular}{|c|c|c|}
\hline & $\begin{array}{l}\text { 3. American Association of } \\
\text { Colleges of Nursing Advancement } \\
\text { Conference (AACN) - March } \\
2006\end{array}$ & $\begin{array}{l}\text { faculty liaison, board chair, board } \\
\text { member. }\end{array}$ \\
\hline $\begin{array}{l}\text { School Board Access database } \\
\text { linked to Banner System }\end{array}$ & Designed and completed & $\begin{array}{l}\text { Administrative assistance in the } \\
\text { School of Nursing and } \\
\text { Development staff. }\end{array}$ \\
\hline Fundraising & $\begin{array}{l}\text { 1. Board members are } \\
\text { knowledgeable advocates for each } \\
\text { of the fundraising priorities. } \\
\text { 2. A structured fundraising plan } \\
\text { has been developed for the } \$ 1 \\
\text { million Learning Resource Center } \\
\text { project... }\end{array}$ & $\begin{array}{l}\text { 1. } 11 \text { board members. } \\
\text { 2. } \$ 70,000 \text { in gifts for priority } \\
\text { projects was received prior to the } \\
\text { launch of the campaign for } \$ 1 \\
\text { million. } \$ 475,000 \text { has been } \\
\text { committed or is in serious } \\
\text { negotiation toward the } \$ 1 \text { million } \\
\text { goal since the formal launch of } \\
\text { fundraising in January } 2006 \text {. }\end{array}$ \\
\hline Dissemination & $\begin{array}{l}\text { (1) "Nursing School Advisory } \\
\text { Board Development and } \\
\text { Operation": workshops presented } \\
\text { at the March 10-11 AACN } \\
\text { Advancement Professionals } \\
\text { Conference; (2) Submission to } \\
\text { Jesuit Advancement Association } \\
\text { (JAA) } 2006 \text { Recognition Awards } \\
\text { Program. }\end{array}$ & $\begin{array}{l}\text { (1) Presentation Team: Nursing } \\
\text { Dean, Faculty Liaison, Board } \\
\text { Chair, Advancement Liaison } \\
\text { (2) Submission Team: } \\
\text { Advancement Liaison, AVP } \\
\text { Development, Dean }\end{array}$ \\
\hline
\end{tabular}

References 
American Association of Colleges of Nursing Advancement Professionals Network. (2006) March 2006 Nursing Advancement Professionals Conference: Building Blocks for Success. Retrieved June 3, 2006 from http://www.aacn.nche.edu/Networks/NAP.htm

BoardSource. (2006). Retrieved June 3, 2006 from http://www.boardsource.org/Workshops.asp

BoardSource. (2005). The source: twelve principles of governance that power exceptional boards. Washington, DC: BoardSource

Council for the Advancement and Support of Education (CASE). (2006) Development for Deans Conference. Retrieved June 3, 2006 from www.case.org.

Fitzpatrick, J.J. \& Deller, S.S. (2000) Fundraising Skills for Health Care Executives. New York, N.Y.: Springer Publishing Company, Inc.

Foundation Center. (2006) Nonprofit Boards and Fundraising. Retrieved June 3, 2006 from http://fdncenter.org/marketplace/catalog/subcategory_training.jhtml?id=cat220001

Giving USA, a publication of Giving USA Foundation, researched and written by the Center on Philanthropy at Indiana University. (2005). Retrieved June 9, 2006 from http://www.aafrc.org/gusa/GUSA05_Press_Release.pdf.

Larsen, E (1993). Nursing Research and Societal Needs: Political, Corporate, and International Perspectives. Journal of Professional Nursing, 9, 73-78.

Lee, T. (1994). The Advisory Committee Advantage. Creating an Effective Strategy for Programmatic Improvement. ERIC Clearinghouse for Higher Education.

Maude, M., \& Heap, R. (1997). Catapult your development efforts with an advisory council. Fund Raising Management, Vol. 28, Issue 3, P. 5-10.

Schervish, P., O’Herlihy, M., \& Havens, J. (2002). Charitable Giving: How Much, By Whom, To What, and How?. The Non Profit Sector: A Research Handbook. Chestnut Hill, Massachusetts: Yale Press.

University of Maryland. (2006). University Consulting \& Training Services. Retrieved June 8, 
Advisory Boards for Schools of Nursing 26

2006 from http://cf.umaryland.edu/ucts/ 